\title{
LEI DE COTAS E O INGRESSO DE NEGROS NO ENSINO SUPERIOR: O CASO DO CURSO DE DIREITO DA UNIR
}

\author{
QUOTA'S LAW AND THE BLACK ADMISSION TO HIGHER EDUCATION: THE \\ CASE OF THE UNIR LAW COURSE
}

\section{LEY DE CUOTAS E LA ENTRADA DE LOS NEGROS EN LA EDUCACIÓN SUPERIOR: EL CASO DEL CURSO DE DERECHO DE LA UNIR}

\author{
Aparecida Luzia Alzira Zuin ${ }^{1}$ \\ André Luiz Pestana Carneiro ${ }^{2}$
}

\section{RESUMO}

Este trabalho tem, por objetivo, analisar o ingresso de negros no Ensino Superior com base na Lei $\mathrm{n}^{\circ}$ 12.711/2012 (Lei de Cotas) e a implementação desta política pública na Universidade Federal de Rondônia (UNIR), como ainda, traçar o perfil dos estudantes cotistas negros do curso de Direito da Unir (2013-2018). Trata-se de uma pesquisa quali-quanti, de cunho bibliográfico e documental, subsidiada por meio de dados estatísticos que fundamentaram o procedimento técnico e teórico-metodológico numa perspectiva interdisciplinar do Direito com a Educação. Os resultados apontaram a possibilidade da eficiência da Lei de Cotas na inclusão da população negra no Ensino Superior (UNIR) como proposto no compromisso de reparação do panorama étnico-racial brasileiro, de modo que esta ação afirmação para a população negra se justifica em razão das perdas históricas que essa população sempre viveu no Brasil, como ainda no uso das políticas tradicionais ou ditas universalistas que não foram capazes de minimizar os problemas inerentes ao ingresso de negros no ensino público superior. Por isso, a ação afirmativa de ingresso da população negra nas Instituições Públicas de Ensino Superior (IFES) constitui em instrumento para a inclusão e a Justiça Social.

Palavras-chave: Lei de Cotas. Negros. Inclusão social. Reparação étnico-racial.

\footnotetext{
1 Realizou estágio de pós-doutoramento na Università del Salento, Facoltà di Giurisprudenza (Filosofia del Diritto), Lecce-Itália. Tem Pós-Doutorado em Direito, pela Universidade do Estado do Rio de Janeiro - UERJ e Pós-Doutorado em Estudos Culturais pelo Programa Avançado de Cultura Contemporânea (PACC/UFRJ). Doutora e Mestra em Comunicação e Semiótica (PUC-SP). Professora visitante no Programa de Pós-graduação Estudos em Direitos Humanos, do Ius Gentium Conimbrigae/Centro Universitário de ensino e investigação na área de Direitos Humanos, da Faculdade de Direito - Universidade de Coimbra (Portugal). Docente do Mestrado Profissional Interdisciplinar em Direitos Humanos e Desenvolvimento da Justiça (DHJUS) e Mestrado Acadêmico em Educação (PPGE/UNIR). Afiliação:Universidade Federal de Rondônia - UNIR

Lattes: http://lattes.cnpq.br/1584841068017210. ORCID: https://orcid.org/0000-0002-5838-2123

e-mail:alazuin@gmail.com

${ }^{2}$ Mestre em Educação pela Universidade Federal de Rondônia (PPGE/UNIR). Pós-Graduado em Direito Eleitoral e Processo Eleitoral pelo Centro Universitário Claretiano (2014/1). Graduado em Direito pela Universidade Federal de Rondônia - UNIR. Membro pesquisador do Centro de Estudos e Pesquisas Jurídicas da Amazônia CEJAM, com ênfase em Políticas Públicas Educacionais. Atualmente é ocupante do cargo de Auditor Interno na Universidade Federal de Rondônia - UNIR. Especializado em Legislação de Pessoal, Aposentadoria em Pensões. Tem experiência na área de Direito, com ênfase em Direito Público. Pesquisador na área de Direito e Educação; Políticas Públicas; Ações Afirmativas. Afiliação: Universidade Federal de Rondônia - UNIR.

Lattes: http://lattes.cnpq.br/176303920953394. ORCID: http://orcid.org/0000-0001-6862-9487

e-mail:advandrepestana@hotmail.com
} 


\begin{abstract}
This study aimed to analyze the entry of blacks into higher education based in Law $\mathrm{n}^{\mathrm{r}}$ 12.711/2012 (Law of Quotas) and the implementation of this public policy at the Federal University of Rondônia (UNIR), as well as, to draw the profile of the black quota students of the Unir Law course (2013-2018). It is a qualitative and quantitative research, bibliographical and documentary, subsidized by means of the statistical data that based the technical and theoretical-methodological procedure in an interdisciplinary perspective of Law with the Education. The results pointed to the possibility of the efficiency of the Quota of Law in the inclusion of the black population in higher education (UNIR) as proposed in the commitment to repair the brazilian ethnic-racial panorama, so that this affirmative action for the black population is justified by virtue of the historical losses that this population has always lived in Brazil, as well as in the use of traditional or so-called universalist policies that have not been able to minimize the problems inherent in the entry of blacks in higher public education. Therefore, the affirmative action ticket of the black population in the Public Institutions of Higher Education is an instrument for justice and social inclusion.
\end{abstract}

Keywords: Quota’s Law. Blacks. Social inclusion. Ethnic-racial reparation.

\title{
RESUMEN
}

Este trabajo tiene por objetivo analizar el ingreso de negros en la educación superior con base en la Ley $n^{\circ} 12.711 / 2012$ (Ley de Cuotas) y la implementación de esta política pública en la Universidad Federal de Rondônia (UNIR), como también, trazar el perfil de los estudiantes cotistas negros del curso de Derecho de la Unir (2013-2018). Se trata de una investigación cualitativa y cuantitativa, de cuño bibliográfico y documental, subsidiada por medio de los datos estadísticos que fundamentan el procedimiento técnico y teórico-metodológico en una perspectiva interdisciplinaria del Derecho con la Educación. Los resultados apuntaron la posibilidad de la eficiencia de la Ley de Cuotas en la inclusión de la población negra en la educación superior (UNIR) como propuesto en el compromiso de reparación del panorama étnico-racial brasileño, de modo que la acción afirmativa para la población negra se justifica en virtud de las pérdidas históricas que esa población siempre vivió en Brasil, como en el uso de las políticas tradicionales o dichas universalistas que no fueron capaces de minimizar los problemas inherentes al ingreso de negros en la enseñanza pública superior. Por eso, la acción afirmativa de la entrada de la población negra en las instituciones públicas de educación superior (IFES) constituye un instrumento para la justicia y la inclusión social.

Palabras clave: Ley de cuotas. Negro. Inclusión social. Reparación étnico-racial.

\section{INTRODUÇÃO}

O presente trabalho propõe, com base na Lei $\mathrm{n}^{\circ} 12.711 / 2012$, mais conhecida como Lei de Cotas, analisar o ingresso de negros no Ensino Superior público, em particular na Universidade Federal de Rondônia (UNIR); como ainda, traçar o perfil dos estudantes cotistas 
negros, do curso de Direito desta Instituição Federal de Ensino Superior (IFES).

Para compreendermos a relevância dos estudos, dados atuais demonstram que pela primeira vez, no Brasil, em 2018, o número de negros no Ensino Superior público superou o número de branco de acordo com a pesquisa "Desigualdades Sociais por Cor ou Raça no Brasil", com base na Pesquisa Nacional por Amostra de Domicílios Contínua - PNAD Contínua, realizada pelo Instituto Brasileiro de Geografia e Estatística (IBGE, 2019). Consta no relatório da pesquisa, de modo mais conclusivo que, "com a trajetória de melhora nos indicadores de adequação, atraso e abandono escolar, estudantes pretos ou pardos passaram a compor maioria nas instituições de ensino superior da rede pública do País (50,3\%), em 2018" (IBGE, 2019, p. 9). Entretanto, assinala o Instituto (2019, p. 9), os negros seguiam, no mesmo ano, sub-representados, visto que constituíam $55,8 \%$ da população, o que respalda a existência das medidas que ampliam e democratizam o acesso à rede pública de ensino superior.

A fim de respaldar a existência das medidas possibilitadoras da ampliação e democratização do ensino público superior, no Brasil, a Lei nº12.711/2012 (Lei de Cotas) destina 50\% das vagas em Universidades e Institutos Federais para estudantes oriundos de escolas públicas, considerando critérios, tais como origem escolar (escola pública), renda familiar e raça. Mas, particularmente, a delimitação do tema recai sobre as cotas para a população negra, ou seja, o foco principal é a investigação sobre a adoção desta política de ação afirmativa no Ensino Superior público para o segmento afrodescendente, o que não exclui a citação de políticas afirmativas destinadas a outros grupos considerados "minorias", como indígenas, pardos e portadores de deficiências.

As políticas públicas são entendidas aqui como ações do Estado voltadas à sociedade, desenvolvidas por diferentes governantes ou pela própria sociedade civil em determinados períodos. Como método de superação e efetivação da igualdade material (real) entre os diversos segmentos étnicos do país, as ações afirmativas podem contribuir para a inclusão de forma justa, mesmo sendo gradual, àqueles que não têm acesso pleno aos direitos sociais fundamentais, possibilitando a equidade e a justiça social, caso conferido no ingresso dos negros nas IFES.

A fim de relacionar a importância da Lei de Cotas como possibilitadora ao ingresso de negros no ensino superior público, foi necessária a compreensão do histórico de exclusão desta população na sociedade brasileira. Por isso, inicia apresentando a história de exclusão do negro desde a Lei de Feijó, perpassando pela Lei Áurea e as Constituições brasileiras; em seguida, apontam-se as dificuldades que a população afrodescendente enfrentou para o ingresso no Ensino Superior e a luta em busca pelo direito à educação, e, por fim, como a Universidade 
Federal de Rondônia (UNIR) desenvolve essa política de ação afirmativa para a inclusão de negros, particularmente no curso de Direito. Elegeu-se o curso de Direito por ser o segundo curso mais concorrido na lista da concorrência para o ingresso desta IFES, atrás do curso de Medicina.

\section{TUDO COMO ANTES NA HISTÓRIA dE EXCLUSÃO DO NEGRO NA EDUCAÇÃO BRASILEIRA: DAS LEIS “ABOLICIONISTAS" ÀS CONSTITUIÇÕES REPUBLICANAS}

A história de exclusão e marginalização do negro no Brasil já é conhecida, mas merece sempre ser relembrada para chamar a atenção e a responsabilidade social sobre o assunto. Embora se diga ou se escreva que a escravidão tenha sido abolida e os negros libertados, em pleno século XXI com o avanço do sistema jurídico e a defesa dos direitos fundamentais, as injustiças com os negros e as negras no País ainda são alarmantes.

No que tange a questão dos direitos e das dificuldades em implementá-los no Brasil, vale revisitar a história com a promulgação da Lei Feijó, de 7 de novembro de 1831. Foi por meio desta Lei que se proibiu o tráfico de escravos, todavia, mesmo com a referida legislação houve o aumento do número de negros marginalizados e explorados na situação de escravos, sem qualquer direito à melhoria de vida, afinal, a proibição não favorecia em nada àqueles que já estavam escravizados, mas tão somente que outros negros não fossem trazidos para o Brasil como escravos, a fim de atender uma exigência, principalmente comercial, por parte da Inglaterra. Assim a Lei Feijó (1831), ao declarar livre todos os escravos vindos de fora do Império, e impondo penas aos importadores escravocratas, não contribuiu para a inclusão dos negros na sociedade brasileira, como cidadãos livres e de direitos.

Não diferentemente ocorreu com a abolição da escravatura em 1888, através da Lei Áurea. A Lei Áurea, oficialmente Lei no 3.353 de 13 de maio de 1888, foi o diploma legal - que extinguiu a escravidão no Brasil. O texto da lei era composto apenas de dois artigos: "Artigo $1^{\circ}$ - É declarada extinta a escravidão no Brasil. Artigo $2^{o}$ - Revogam-se as disposições em contrário. " Ou seja, ao longo da história, mesmo após a abolição nos termos que foram aprovados os dois artigos da Lei Áurea, a população negra passou a enfrentar os mesmos processos de discriminação e exclusão, consequentemente, sem acesso aos direitos básicos de saúde, educação, moradia e trabalhos dignos. Afinal, o que se analisar e reivindicar em termos jurídicos e de direitos os dispositivos constantes na lei. Diz-se - extinta a escravidão; diz-se revogam-se as disposições em contrário; e ponto final. 
Segundo Fanon (2008, p. 12), desde os tempos da escravidão "o negro era privado de sua cultura e consciência em razão da exacerbação do ideal social capitalista, no qual o branco impunha aos negros a condição de ser superior". Isso significou que a abolição não destinou acesso aos direitos, como também não devolveu a dignidade humana à população negra no Brasil.

De acordo com Oliveira (2004, p. 48), "ainda que livres, os negros permaneciam proibidos de frequentarem a escola, por exemplo, isto é, nada se fez de forma oficial para que pudessem ter melhores condições de vida por meio da educação". E, passados quase quatro séculos depois, o negro ainda permanecia nessa condição, sem direito a praticamente nenhum serviço público disponibilizado pelo Estado ou qualquer reconhecimento nos direitos civis, apesar da intensa miscigenação entre os povos negros, europeus e os indígenas.

Para o tratado da educação, de acordo com Anísio Teixeira (1969, p. 42), a escola da elite brasileira, no fim do período colonial, era composta predominantemente pelos filhos dos antigos proprietários rurais e da nascente classe comercial que abrangia a escola secundária de caráter "pseudo-humanístico" e a escola superior. Para o povo - excluindo-se os negros livres -, "havia a escola primária, a escola de artes e ofícios e a escola normal, em dois sistemas independentes" (TEIXEIRA, 1969, p. 42).

Novamente se observa que os negros deixaram a condição de servidão, mas não obtiveram o apoio oficial de assistência ou transição por parte do governo imperial, ficando, consequentemente, sujeitos à miséria e à marginalização social. Se a inclusão socioeconômica e educacional viria por meios oficiais, o que se tem é que por meios legais não ocorreu, ou seja, a inclusão dos negros não estava regida em nenhuma legislação pertinente ao caso.

No histórico das Constituições brasileiras isso é fato notório. Desde a Independência (1822), assim como a Constituição (1824), que conduziu o território brasileiro por quase 67 anos,

[...] não trouxe os avanços necessários para a educação. [...] apesar de contar com um artigo referente à educação, também deixa muito a desejar em termos de políticas educacionais: determina a instrução primária gratuita para todos os cidadãos, porém, não considera assim os negros e os pobres. (IOSIFGUIMARÃES, 2009, p. 45) (grifos nossos)

Na primeira Constituição, a de 1824, o texto constitucional declarou a igualdade de todos os cidadãos perante a lei. Contudo, essa mesma Constituição excluiu da definição de cidadão a população escravizada, a qual não era assegurado qualquer direito civil ou mesmo eram reconhecidos como cidadãos brasileiros. Nesta Constituição a educação foi apresentada como instrução, e, mesmo assim houve menção apenas duas vezes sobre o tema, no artigo em 
que tratava sobre a "inviolabilidade dos direitos civis e políticos dos cidadãos", quando se estabeleceu "a instrução primária e gratuita a todos os cidadãos" e tratou ainda, sobre os "colégios e universidades onde serão ensinados ciência, belas letras e artes". (BRASIL, 1824, ART. 179, XXXII E XXXIII).

Percorrendo a história, ao final do Império, intensificaram-se os debates sobre a necessidade da educação pública associada aos temas sociais que alteraram significativamente o panorama da sociedade brasileira como a Abolição da Escravatura, o incentivo à imigração estrangeira e à modernização técnica da produção pela introdução de máquinas; também com o avanço do modelo republicano do País e a necessidade de formação do trabalhador. Segundo Saviani (2004, p. 22), "pensava-se na instituição da escola pública e na adoção do sistema agrícola para criar o gosto pelo trabalho ao homem livre e ao ex-escravo recém-liberto".

A Constituição Republicana de 1891 ampliou os direitos de participação ao voto do cidadão, mas impôs a alfabetização como critério para o direito ao voto, em um contexto em que praticamente toda a população negra era analfabeta. Fato é que com essa Constituição, não se estabeleceu nenhuma inovação significativa em relação à Constituição de 1824, deixando de lado questões importantes que pudessem incluir os negros na educação, tais como a gratuidade e a obrigatoriedade da educação pública a todos os cidadãos independente de raça, religião, condição socioeconômica, etc. O que ocorreu foi a isenção do Estado ao favorecimento desse direito a quem dele necessitasse.

Por outro lado, a Constituição de 1891 conferiu aos estados e municípios como únicos responsáveis pela educação primária e essencial para a população negra livre, recémescravizada e recém-liberta. A Constituição de 1891 regeu o País por 43 anos, e nesse período houve cinco Reformas na matéria da educação, a saber: Reforma de Benjamin Constant (decreto n 081/1890); Reforma de Epitácio Pessoa (decreto no 3.890/1901); Reforma de Rivadávia Corrêa (decreto $\mathrm{n}^{\circ}$ 8.659/1911); Reforma de Carlos Maximiliano (decreto ${ }^{\circ}$ 11.530/1915); e a Reforma de João Luís Alves ou Lei Rocha Vaz (decreto n 16.780-A/1925) (SILVA; ARAÚJO, 2005).

A partir de 1930, há uma nova mudança em relação à educação pública. A década de 1930 é reconhecida como o marco referencial da modernidade na história do Brasil; modernidade entendida como processos de industrialização e urbanização, contemplada por inúmeros estudos que destacam esse período pelas transformações que inauguraram e os movimentos políticos que as protagonizaram - a Revolução de outubro de 1930 e o Estado Novo, oficialmente instalado em 1937. 
A Constituição de 1934, por sua vez, inovou no aspecto referente à igualdade, prescrevendo no art. 113 a igualdade entre os cidadãos, independentemente de nascimento, sexo, raça, profissões próprias ou dos pais, classe social, riqueza, crenças religiosas ou ideias políticas. O termo raça foi empregado nos sentidos de cor da pele e etnia (especificamente: negro, branco, indígena). Além dos termos novos que surgiram para justificar ou defender a igualdade, foi a primeira Carta Magna a fixar como competência privativa da União traçar as diretrizes da educação (art. $5^{\circ}$ ), como forma de organizar a área educacional em âmbito nacional com vistas à consolidação do sistema de educação pública. Por outro lado, foi a que menos durou em toda a história legislativa brasileira: apenas três anos, tendo vigorado oficialmente apenas um ano, já que foi suspensa pela Lei de Segurança Nacional (Lei no 6.620/1978), em vigor à época. Não obstante a fixação da competência para a União traçar as diretrizes da educação nacional, novamente, não houve alterações significativas para a educação básica, apenas para o ensino superior, no que se refere à autonomia universitária.

Em virtude da expansão do regime de Estados socialistas no mundo, após a Primeira Guerra Mundial, e graças aos ideais sociais que envolveram a promulgação da Constituição de 1934, instalou-se o Estado Novo, pelo presidente Getúlio Vagas, legitimado pela Constituição de 1937; e trouxe à tona a concentração da maior parte dos Poderes da República no Poder Executivo (o presidente da República). Na área da educação, permaneceu a competência da União para legislar sobre as diretrizes e bases da educação nacional, mas delegou-se à família a responsabilidade primária para a educação dos filhos e ao Estado a colaboração secundária (art. 125). Para Cury (2014, p. 34):

[...] a Constituição de 1934 trouxe grandes avanços como a gratuidade e a obrigatoriedade do ensino primário, o plano nacional de educação e a institucionalização dos conselhos de educação. E, para que essas medidas se tornassem efetivas, adotou-se a obrigatoriedade de destinar um percentual dos impostos para a educação, percentuais diferentes para a União, estados e municípios. Tal determinação sempre vigorou quando o país usufruiu de regimes democráticos e a perdeu toda vez que esteve sob os regimes autoritários.

A Constituição de 1937, outorgada em 10 de novembro, foi fruto de um golpe militar, inspirada nas constituições dos regimes fascistas europeus, com caráter autoritário (IOSIFGUIMARÃES, 2009). Para Iosif-Guimarães (2009, p. 51) a Constituição de 1937 representou um grande retrocesso na área educacional, "revogando a vinculação de recursos para a educação e reforçando a dualidade entre a escola de ricos e pobres, apesar de manter alguns princípios da Carta anterior"; consequentemente, aumentando o distanciamento da população negra das escolas públicas. Segundo Ghiraldelli Junior (2009, p. 79): 


\begin{abstract}
A intenção da Carta de 1937 era manter, e talvez aprofundar, um explícito [...] dualismo educacional: os ricos proveriam seus estudos através do sistema público ou particular e os pobres, sem usufruir desse sistema, deveriam ter como destino as escolas profissionais ou, se quisessem, teriam de contar com a boa vontade dos ricos para com as "caixas escolares".
\end{abstract}

$\mathrm{Na}$ Constituição de 1946, questões como a responsabilidade do dever de educar; o ensino religioso; o financiamento da educação, entre outras; foram amplamente discutidas. Muitos dos direitos que já haviam sido garantidos na Constituição de 1934 retornaram, como a questão da educação enquanto um direito subjetivo público, e competia à União, em vez de traçar diretrizes (CF/1934) ou fixar as bases (CF/1937), legislar sobre as Diretrizes e Bases da Educação Nacional (CF/1946). Quanto ao financiamento da educação, retomou-se o texto da Constituição Federal de 1934, estabelecendo que a União aplicasse para a manutenção e o desenvolvimento do ensino nunca menos de $10 \%$, e os estados, o Distrito Federal e os municípios nunca menos de $20 \%$ da renda que resultasse dos impostos (BRASIL, 1946). Por outro lado, não se fez qualquer menção aos negros, indígenas ou mesmo à população de baixa renda, como constava no texto da Constituição de 1934.

Durante os anos de 1964 e 1970, a ditadura civil-militar suprimiu muitas formas de liberdade intelectual, artística e atividade política, dificultando a organização dos movimentos sociais, especialmente, dentre eles, o Movimento Negro. Contudo, isto não impediu que surgissem várias formas de resistência cultural negra, notadamente nos grandes centros urbanos do País.

Passado o período do regime militar que perdurou entre 1964 e 1985 que deixou o Brasil sem avanços na área educacional, principalmente sem sobre a inclusão dos negros e indígenas no sistema de educação, em 1987 instalou-se a Assembleia Nacional Constituinte, espaço político considerado importante para as vozes dos movimentos sociais reivindicarem seus direitos naquele momento.

Com a aprovação em 22 de setembro de 1988 e promulgada em 5 de outubro de 1988, a Constituição Federal (CF/88), chamada de Constituição Cidadã, considerando o contexto mundial de priorização da educação e pesquisa científica, foi a que mais se aproximou das questões referentes às políticas públicas, formas de universalização e inclusão social como maneira de diminuir as disparidades regionais existentes no País, consagrando as conquistas e a mobilização da comunidade educacional, assim como os diversos movimentos sociais organizados presentes na agenda constitucional. Destarte, por serem normas programáticas, os assuntos na área da educação dependem efetivamente da atuação dos governos municipal, 
estadual e federal.

Segundo Saviani (2004, p. 46), entre as principais conquistas da CF/88 estão o direito à educação a partir do nascimento, a gratuidade do ensino público em todos os níveis (básico, fundamental, médio e superior). Na área do ensino superior, a Constituição da República Federativa do Brasil de 1988 ousou ainda mais com relação aquelas anteriores, e deu às instituições públicas de ensino superior plena autonomia didático-científico-administrativa e de gestão financeira e patrimonial, obedecendo ao princípio de indissociabilidade entre ensino, pesquisa e extensão.

\subsection{O Movimento Negro e a luta pelo Direito à Educação pública}

No ano de 1995, por ocasião da comemoração dos 300 anos da morte de Zumbi dos Palmares, realizou-se a marcha em direção a Brasília, em 20 de novembro, denominada "Marcha Zumbi dos Palmares Contra o Racismo, pela Cidadania e a Vida" e pela "Libertação dos Negros". Na ocasião, o Movimento Negro entregou ao presidente da República na época, Fernando Henrique Cardoso, um manifesto com reivindicações, exigindo a elaboração de políticas públicas e ações concretas do Estado para oferecer condições à promoção da igualdade de oportunidades e a eliminação de qualquer forma de discriminação racial na sociedade.

Nesse documento (Marcha Zumbi dos Palmaras Contra o Racismo, pela Cidadania e a Vida), constaram as seguintes propostas para melhora na educação brasileira à população negra: a) desenvolvimento de ações afirmativas para o acesso dos negros aos cursos profissionalizantes, às universidades e às áreas de tecnologias de ponta; b) recuperação, fortalecimento e ampliação das escolas públicas, gratuitas e de qualidade; c) implementação da "Convenção sobre Eliminação da Discriminação Racial no Ensino"; d) monitoramento dos livros didáticos, manuais escolares e programas educativos controlados pela União; e) desenvolvimento de programas permanentes de treinamento de professores e educadores que os habilitem a tratar adequadamente a diversidade racial, identificar as práticas discriminatórias presentes na escola e o impacto da evasão e repetência das crianças negras; f) desenvolvimento de programas educacionais de emergência para a eliminação do analfabetismo; g) concessão de bolsas remuneradas para adolescentes negros de baixa renda para o acesso e conclusão dos ensinos Fundamental e Médio.

Somada à autonomia outorgada às universidades públicas, surgiu a política pública de ações afirmativas, cujo objetivo é a de disponibilizar parte das vagas aos negros, tendo em vista 
a estagnação dos números referentes à escolaridade entre negros em relação à população branca e eliminar os efeitos persistentes da discriminação do passado, que tende a se perpetuar se não houver mecanismos de inclusão social para a população negra brasileira na educação.

No ano de 2008, o Instituto Brasileiro de Geografia e Estatística (IBGE) realizou a primeira Pesquisa das Características Étnico-raciais da População (PCERP) nos estados do Amazonas, Paraíba, São Paulo, Rio Grande do Sul, Mato Grosso e Distrito Federal. Nos resultados da pesquisa, dispostos no gráfico 1, verificou-se que entre os brancos com a idade de 15 anos ou mais, 20,3\% dos entrevistados possuíam até 4 anos de estudo; praticamente a mesma proporção dos indivíduos - 20,4\% declararam ter de 5 a 8 anos de estudo; 36,2\% estudaram 9 a 11 anos, sendo esta a faixa modal do grupo de brancos em termos de escolaridade; e 23,0\% declararam 12 anos ou mais (IBGE, 2008). Entre os autodeclarados pardos, 19,1\% possuíam escolaridade de até 4 anos; $25,1 \%$ estudaram de 5 a 8 anos; 43,9\% concluíram 9 a 11 anos; e 11,8\% declararam possuir tempo de estudo igual ou superior a 12 anos. Já os entrevistados que se declararam pertencentes à cor, ou raça, preta/negra, notou-se que 24,7\% possuíam até 4 anos de estudo; 29,4\% estudaram 5 a 8 anos; 37,5\% declararam ter estudado 9 a 11 anos; e apenas 8,5\% concluíram 12 ou mais anos de estudo (IBGE, 2008).

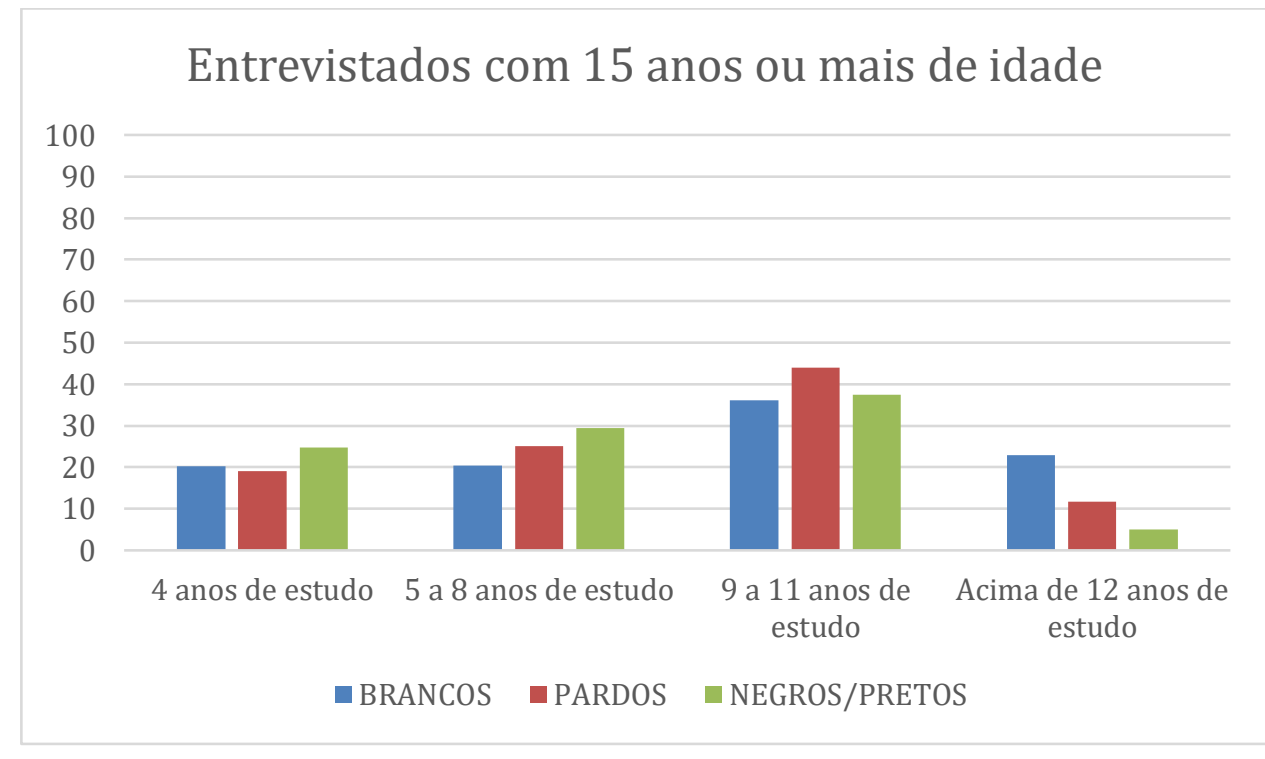

Fonte: Elaborado pelos autores

Reconhece-se por meio dos dados do IBGE (2008) que quanto maior o nível de escolaridade, considerando os anos de estudo, a população negra (que inclui pretos e pardos) está em desvantagem considerando a taxa de sucesso (inclusão, permanência e conclusão do ensino). Se no ensino secundário (hoje ensino médio) demorou o acesso aos negros, não diferentemente ocorreu com o ensino superior. Este nível de escolarização foi, por muitos 
séculos e décadas, reservado à classe dominante, segundo Anísio Teixeira (1969), pois, no Brasil, não se expandia o ensino secundário de qualidade e público para a maioria da sociedade brasileira, sendo esse o caminho facilitador de brancos e mais abastados financeiramente para alcançar o Ensino Superior, assim: "seguia-se para as classes mais abastadas da sociedade" (TEIXEIRA, 1969, p. 42), o que não incluía a população negra.

Nesse contexto, merece lembrar de Paulo Freire (1988) na discussão sobre a educação enquanto processo político. $\mathrm{O}$ acesso ao conhecimento é um processo político, porque aumenta as possibilidades de o indivíduo alcançar melhores condições de vida. Ainda segundo Freire, essa educação como processo político é um ato de problematização dos homens sobre o mundo: "É práxis que implica a ação e a reflexão dos homens sobre o mundo para transformá-lo" (FREIRE, 1988, p. 67).

Se é por meio da educação e/ou do ensino (frequentar a escola ou universidade) que o cidadão pode almejar melhores condições de vida, é aqui que entra a discussão sobre a política de ação afirmativa, mais especificamente a Lei nº 12.711/2012 -Lei de Cotas. Esta política está notadamente associada à ideia de inclusão e transformação socioeconômica e cultural do negro na sociedade.

\section{LEI DE COTAS E SEU IMPACTO PARA O ACESSO DA POPULAÇÃO NEGRA NO ENSINO SUPERIOR}

Política de ações afirmativas podem ser definidas como políticas que beneficiam ativamente grupos, não relativamente minoritários, socialmente desfavorecidos na destinação de diretrizes específicas, a fim de fomentar a inclusão dos mesmos em áreas como: mercado de trabalho, vagas nas universidades e contratos públicos e, objetivam concretizar a igualdade material.

A ideia de ação afirmativa abrange políticas que visam combater o racismo existente na sociedade e corrigir efeitos de racismos históricos, como no caso do Brasil, idealizando a igualdade material (não apenas a formal, do texto da Lei) de acesso aos bens fundamentais em uma democracia sólida, como é o caso da Educação Superior. São políticas/ações não simplesmente voltadas para a intervenção posterior, mas com caráter político e múltiplo de ação, tanto sobre os efeitos da desigualdade histórica quanto sobre o racismo atual, - pode-se afirmar que atua ainda como uma prevenção a um futuro aumento do racismo. 
Assim, o caráter múltiplo das ações afirmativas nos remete ao objetivo principal: atingir a igualdade racial no imaginário coletivo real, induzindo às transformações de ordem cultural, pedagógica e psicológica. Nessa perspectiva, o objetivo das ações afirmativas não é, essencialmente, coibir o racismo, mas promover a igualdade racial, proporcionado a diversidade e a representatividade estatal e social, eliminado as barreiras raciais, artificiais e invisíveis (SANTOS, 2005).

Isso ocorre quando a democracia é o instrumento de exercício de diversos valores conquistados pelo homem, pautados na dignidade da pessoa humana, e que, no passar do tempo, se transformaram em direitos fundamentais (SILVA, 2007, p. 126). Esses valores são a vontade soberana do povo como a legítima vontade e ação a ser aplicada pelo governante, não havendo espaço aos interesses pessoais ou de grupos determinados, mas sim, com interesses difusos, impessoais.

Com isso, ingressar, frequentar e concluir um nível de ensino se transforma em uma vantagem ou até mesmo em um ato político e de ascensão social que esse ensino possa oferecer, o que acaba por incentivar a procura por esse direito - o ingresso na escola, principalmente, ingressar, frequentar e concluir o ensino superior como apresentado aqui. É nessa esteira que Anísio Teixeira, desde 1969, apontava a democracia vincula ao ato da educação.

[...] a democracia não pode existir sem educação para todos e cada um, pois importa em transformar, não alguns homens, mas todos os homens para - contra tendências hereditárias, sociais, se não biológicas - rematar, por evolução consciente, a obra que as sucessivas civilizações, desde o começo dos séculos, vêm realizando pela injustiça e consequente violência. Todas as outras formas de sociedade precisam de alguma educação, mas só a democracia precisa de educação para todos e na maior quantidade possível $(1969$, p. 220).

O surgimento dos direitos fundamentais de terceira geração evidencia uma tendência orientada à expansão do que viria a ser o sujeito de direitos e a própria conceituação e entendimento de dignidade humana, como aqui se apregoa à questão da dignidade dos negros enquanto sujeitos de ação política.

Para Anísio Teixeira, a democracia em seus direitos fundamentais nos documentos legais pregava a liberdade de expressão, de reunião e organização, que, ao lado da liberdade de ir e vir, estava sempre subordinada a uma condição fundamental: o direito à educação $(1969$, p. 17). Nesse sentido, a defesa da Lei das Cotas vai ao encontro dessa concessão, porque o que se prevê é que haja a diminuição das disparidades entre as classes sociais e/ou étnicas, em vista da igualdade como direito fundamental. Por isso, a inclusão social, que está associada à dignidade da pessoa humana, porque tende a proporcionar a participação dos mais pobres e/ou negros(as) 
(o que inclui pretos e pardos) na comunidade acadêmica, elevando, portanto, o grau de escolaridade desses grupos; e, a médio prazo, a diminuição do "“abismo" socioeconômico entre as diferentes classes sociais que compõem a sociedade brasileira, contribuindo, também, para eliminar o estigma social da origem da população negra" (BRANDÃO, 2005, p. 88). O que significaria, portanto, a efetivação da Justiça social.

\subsection{Justiça Social por meio das cotas: o caso da inclusão dos negros no curso de Direito da UNIR}

O Fórum Nacional de Pró-Reitores de Assuntos Comunitários e Estudantis (Fonaprace) em parceria com Associação Nacional dos Dirigentes das Instituições de Ensino Superior (ANDIFES), com a finalidade de traçar o perfil socioeconômico e cultural dos mais de 1 milhões de estudantes da graduação pública federal, realiza periodicamente pesquisa em âmbito nacional. Na pesquisa realizada pelo Fórum em 2010, que teve a participação, na época, de vários estudantes das 56 Instituições Federais de Ensino Superior (IFES), constatou-se que $43,74 \%$ dos alunos das universidades federais pertenciam às classes C, D e E; e que o porcentual de estudantes de raça/cor/etnia preta aumentou de 5,9\% em 2004 (período da pesquisa anterior) para 8,7\%, em 2010 (FONAPRACE, 2010).

Em 2018³, o número de graduandos(as), de campi e a razão número de graduandos/número de campi, por região onde se localizam os campi - 2018, estava assim disposto:

Tabela 1: Número de graduandos (as), de campi e a razão número de graduandos/número de campi, por região onde se localizam os campi - 2018

\begin{tabular}{cccc}
\hline Região & $\begin{array}{c}\text { No. de } \\
\text { graduandos }\end{array}$ & No. de campi & $\begin{array}{c}\text { Razão } \\
\text { graduandos/campi }\end{array}$ \\
\hline Norte & 151.181 & 69 & $2.191,04$ \\
Nordeste & 355.041 & 102 & $3.480,79$ \\
Sudeste & 360.160 & 107 & $3.365,98$ \\
Sul & 209.887 & 75 & $2.798,49$
\end{tabular}

\footnotetext{
${ }^{3}$ FONAPRACE. O universo investigado pela V Pesquisa foi composto por estudantes de cursos de graduação presenciais de todas as 63 universidades federais existentes até fevereiro de 2018, bem como pelo Centro Federal de Educação Tecnológica de Minas Gerais e pelo Centro Federal de Educação Tecnológica Celso Suckow da Fonseca, do Rio de Janeiro, totalizando 65 IFES. Ao final do processo de cadastramento de estudantes, chegou-se ao volume de 1.200.300 (um milhão, duzentos mil e trezentos) discentes, distribuídos por 65 IFES e por $395 \mathrm{campi}$, ingressantes no período entre 2000-2018. Estes discentes têm matrícula ativa em 355 cursos, distribuídos nos turnos Diurno, Noturno e Integral, para obtenção dos graus de Bacharelado, Licenciatura, Bacharelado e Licenciatura e Tecnológico.
} 


\begin{tabular}{cccc}
$\begin{array}{c}\text { Centro- } \\
\text { Oeste }\end{array}$ & 124.031 & 42 & $2.953,11$ \\
\hline Total & 1.200 .300 & 395 & $3.038,73$
\end{tabular}

Fonte: V Pesquisa Nacional de Perfil Socioeconômico e Cultural dos (as) graduandos (as) das IFES (2018).

Nesta geografia localiza-se a Universidade Federal de Rondônia (UNIR), na região Norte, estado de Rondônia, sendo a única Universidade pública no estado ${ }^{4}$. A universidade possui 8 campi espalhados pelas seguintes cidades: Ariquemes, Cacoal, Guajará-Mirim, JiParaná, Porto Velho, Presidente Médici, Rolim de Moura e Vilhena. Foi fundada pela Lei de n. 7.011 de 8 de julho de 1982, após a criação do estado de Rondônia pela Lei Complementar n..$^{\circ} 41$ de 22 de dezembro de 1981 e a sede administrativa (Reitoria e Pró-Reitorias) está situada na capital Porto Velho.

A partir da aprovação da Lei de Cotas, em 2012, nas universidades federais e nas instituições federais de ensino técnico de nível médio vinculadas ao Ministério da Educação (MEC), ficou estabelecido que deveriam reservar em cada processo seletivo discente, para ingresso nos cursos de graduação, no mínimo 50\% de suas vagas para estudantes que cursaram integralmente o ensino médio em escolas públicas. Importante observar que a lei estipula um mínimo de $50 \%$ de vagas reservadas e desta forma não obsta, portanto, que esse percentual não possa ser superior.

No art. $3^{\circ}$, da referida lei, determina que em cada instituição federal de ensino superior, as vagas de que trata o art. $1^{\circ}$ serão preenchidas, por curso e turno, por autodeclarados pretos, pardos e indígenas e por pessoas com deficiência, nos termos da legislação, em proporção ao total de vagas no mínimo igual à proporção respectiva de pretos, pardos, indígenas e pessoas com deficiência na população da unidade da Federação onde está instalada a instituição, segundo o último censo da Fundação Instituto Brasileiro de Geografia e Estatística - IBGE (BRASIL, 2012). (Redação dada pela Lei nº 13.409, de 2016).

Conforme dados do FONAPRACE/ANDIFES (2018), temos uma importante informação sobre o tratado da inclusão de negros e indígenas no ensino superior, na região Norte, onde se localiza, conforme informado acima, a Fundação Universidade Federal de Rondônia (UNIR). Segundo o documento produzido pelo Fórum isso é produto da diversidade regional brasileira, que pode ser melhor observada ao desagregarmos algumas categorias. A metodologia do Fórum para explicar as categorias foi desenvolvida do seguinte modo:

\footnotetext{
${ }^{4}$ Não inserido o Instituto Federal de Rondônia (IFRO) que oferece ensino superior público no estado.
} 
Substituímos a categoria "preto" do IBGE pelo par "preto não quilombola" e "preto quilombola", uma aproximação que pretende estimar a presença de quilombolas no meio universitário. A categoria indígena foi dividida em duas modalidades, aldeado e não aldeado, que pretende expressar em parte a condição de vida do indígena na universidade, uma vez que as políticas de ação afirmativa para esse grupo populacional estão presentes em todo o sistema federal de ensino superior (FONAPRACE, 2018, p. 62).

Mais, cita o relatório que é notável a maior presença relativa de pretos (as) quilombolas nesta região, ou seja, mais do que o dobro da proporção nacional e, em menor proporção, no Sul, menos da metade da proporção nacional. É também na região Norte que se anota a maior proporção de indígenas, praticamente o triplo da proporção nacional, sejam eles aldeados (as) ou não aldeados (as) (FONAPRACE, 2018). Observa-se abaixo.

Figura 1: Graduandos (as) por cor ou raça, segundo faixa de ano de ingresso - 2018

\begin{tabular}{|c|c|c|c|c|c|c|}
\hline \multicolumn{2}{|c|}{$\begin{array}{l}\text { Cor ou raça/ Faixa } \\
\text { de ano de ingresso }\end{array}$} & \multirow{2}{*}{$\begin{array}{c}\begin{array}{c}\text { Ingressante } \\
\text { até } \mathbf{2 0 1 2}\end{array} \\
3.880\end{array}$} & \multirow{2}{*}{$\begin{array}{c}\begin{array}{c}\text { Ingressante } \\
\mathbf{2 0 1 3}-\mathbf{2 0 1 6}\end{array} \\
14.031\end{array}$} & \multirow{2}{*}{$\begin{array}{c}\begin{array}{c}\text { Ingressante } \\
\mathbf{2 0 1 7}\end{array} \\
4.760\end{array}$} & \multirow{2}{*}{$\begin{array}{c}\begin{array}{c}\text { Ingressante } \\
\mathbf{2 0 1 8}\end{array} \\
2.971\end{array}$} & \multirow{2}{*}{$\begin{array}{c}\text { Total } \\
25.642\end{array}$} \\
\hline & Freq. & & & & & \\
\hline \multirow[t]{3}{*}{ Amarela } & $\%(\mathrm{~L})$ & 15,1 & 54,7 & 18,6 & 11,6 & 100,0 \\
\hline & $\%$ (C) & 2,7 & 2,2 & 2,0 & 1,8 & 2,1 \\
\hline & Freq. & 64.542 & 285.279 & 99.732 & 70.455 & 520.008 \\
\hline \multirow[t]{3}{*}{ Branca } & $\%(\mathrm{~L})$ & 12,4 & 54,9 & 19,2 & 13,6 & 100,0 \\
\hline & $\%(C)$ & 44,6 & 43,8 & 41,5 & 43,2 & 43,3 \\
\hline & Freq. & 51.924 & 253.322 & 98.665 & 66.316 & 470.227 \\
\hline \multirow[t]{3}{*}{ Parda } & $\%(\mathrm{~L})$ & 11,0 & 53,9 & 21,0 & 14,1 & 100,0 \\
\hline & $\%$ (C) & 35,9 & 38,9 & 41,0 & 40,7 & 39,2 \\
\hline & Freq. & 906 & 5.449 & 2.481 & 1.911 & 10.747 \\
\hline \multirow{2}{*}{$\begin{array}{c}\text { Preta - } \\
\text { quilombola }\end{array}$} & $\%(\mathrm{~L})$ & 8,4 & 50,7 & 23,1 & 17,8 & 100,0 \\
\hline & $\%$ (C) & 0,6 & 0,8 & 1,0 & 1,2 & 0,9 \\
\hline \multirow{3}{*}{$\begin{array}{l}\text { Preta - não } \\
\text { quilombola }\end{array}$} & Freq. & 16.774 & 71.636 & 27.507 & 16.934 & 132.851 \\
\hline & $\%(\mathrm{~L})$ & 12,6 & 53,9 & 20,7 & 12,8 & 100,0 \\
\hline & $\%$ (C) & 11,6 & 11,0 & 11,4 & 10,4 & 11,1 \\
\hline \multirow{3}{*}{$\begin{array}{l}\text { Indigena } \\
\text { aldeado }\end{array}$} & Freq. & 455 & 2.234 & 1.157 & 826 & 4.672 \\
\hline & $\%(L)$ & 9,7 & 47,8 & 24,8 & 17,7 & 100,0 \\
\hline & $\%$ (C) & 0,3 & 0,3 & 0,5 & 0,5 & 0,4 \\
\hline \multirow{3}{*}{$\begin{array}{c}\text { Indigena } \\
\text { não aldeado }\end{array}$} & Freq. & 891 & 3.203 & 1.275 & 696 & 6.065 \\
\hline & $\%(\mathrm{~L})$ & 14,7 & 52,8 & 21,0 & 11,5 & 100,0 \\
\hline & $\%$ (C) & 0,6 & 0,5 & 0,5 & 0,4 & 0,5 \\
\hline \multirow{3}{*}{$\begin{array}{c}\text { Sem } \\
\text { declaração }\end{array}$} & Freq. & 5.197 & 16.959 & 4.989 & 2.942 & 30.087 \\
\hline & $\%(\mathrm{~L})$ & 17,3 & 56,4 & 16,6 & 9,8 & 100,0 \\
\hline & $\%$ (C) & 3,6 & 2,6 & 2,1 & 1,8 & 2,5 \\
\hline \multirow{3}{*}{ Total } & Freq. & 144.569 & 652.113 & 240.566 & 163.051 & $1.200 .300^{*}$ \\
\hline & $\%(\mathrm{~L})$ & 12,0 & 54,3 & 20,0 & 13,6 & 100,0 \\
\hline & $\%$ (C) & 100,0 & 100,0 & 100,0 & 100,0 & 100,0 \\
\hline
\end{tabular}

Fonte: FONAPRACE. V Pesquisa Nacional de Perfil Socioeconômico e Cultural dos (as) graduandos (as) das IFES (2018). * Em virtude do arredondamento necessário à padronização da expansão amostral, a soma total de (graduandos) seria 1.200.299 
Pode-se conferir na figura 1 o aumento significativo (\%) de ingressantes da cor ou raça/preta: quilombola \%(L) 50,7; e não-quilombola \%(L) 53,9, no período de 2013-2016, o que se pressupõe ter relação com o período de implementação da Lei de Cotas nas IFES, após a aprovação em 2012. Esses dados, na sequência, são significativamente demonstrados na figura a seguir.

Figura 2: Graduandos (as) por cor ou raça, segundo região geográfica de campus (em \%) - 2018

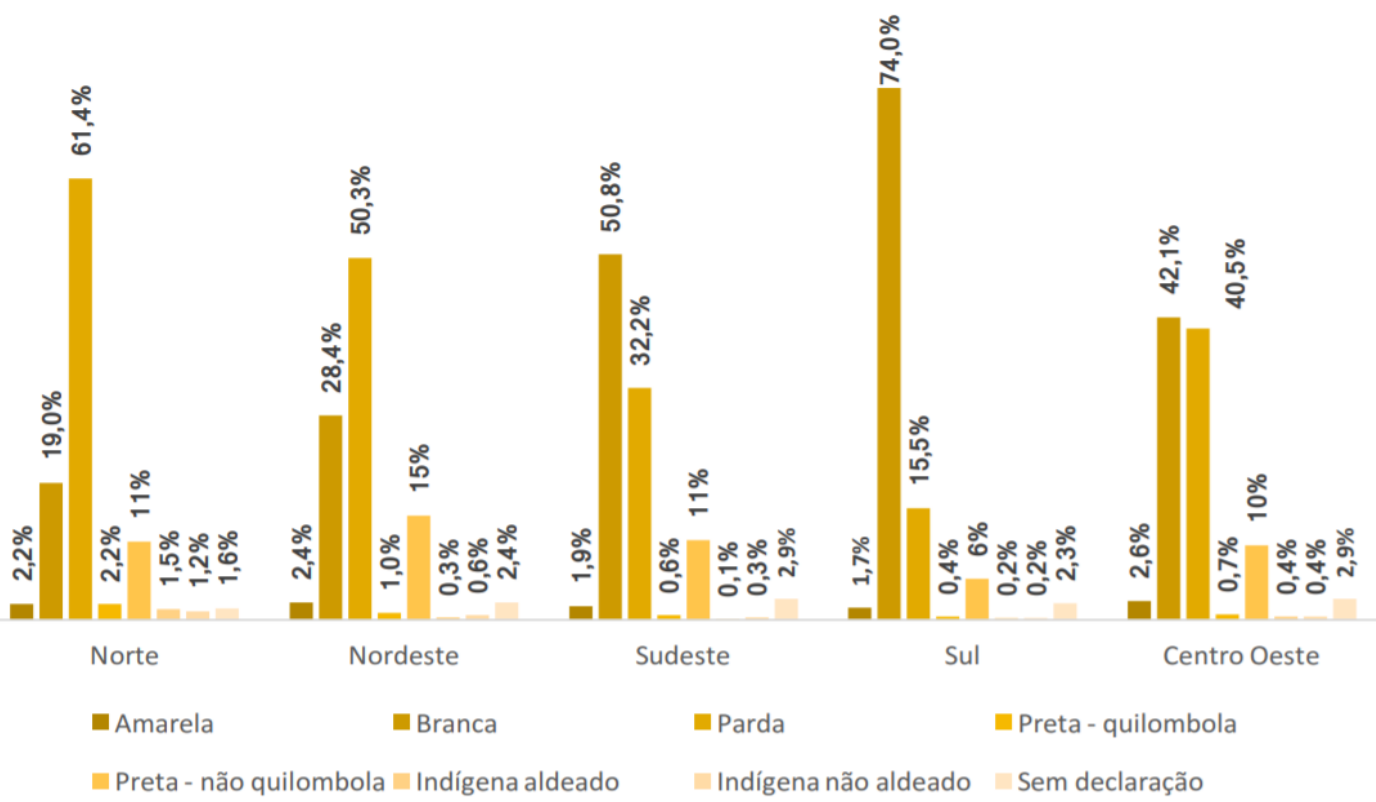

Fonte: FONAPRACE. V Pesquisa Nacional de Perfil Socioeconômico e Cultural dos (as) graduandos (as) das IFES (2018).

Elaborar e concretizar políticas públicas para o acesso dos estudantes negros no ensino superior é promover justiça social com equidade. Autores como Brandão (2005) e Kaufmann (2007) criticam as ações afirmativas por criarem privilégios a determinados grupos, uma vez que a Constituição de 1988 estabelece que todos somos iguais. Por sua vez Piovesan (2012, p.20) lembra que a segregação ocorre quando em situações diferentes somos tratados iguais e em situações iguais somos tratados diferentes. Uma boa parcela da sociedade brasileira ainda nega a existência desses males, sobretudo, na universidade pública brasileira.

Neste diapasão analisamos a aplicação da Lei de Cotas na UNIR dentro do critério "cor/raça" no curso de Direito, do Departamento de Ciências Jurídicas (DCJ), do campus José Ribeiro Filho, Porto Velho-RO. Foi, em atendimento à Lei no 12.711/2012 (Lei de Cotas) que previa a aplicação gradativa das reservas de vagas até o percentual de $50 \%$ estipulado pela norma, que a Universidade Federal de Rondônia (UNIR), em que pese as dificuldades da implantação desta política de ação afirmativa, realizou ano após ano, várias alterações nos processos seletivos na tentativa de se adequar ao que está determinado e no ano de 2013 aplicou 
a reserva de $12,5 \%$ de vagas para as cotas.

Com isso, o curso de Direito em análise, que tem uma oferta semestral de 50 vagas, ficou com uma divisão de 43 vagas para a ampla concorrência e 07 vagas para as cotas. As 7 vagas para as cotas, no primeiro e segundo semestres letivos de 2013, foram distribuídas em: 5 vagas para pessoas autodeclaradas pardas, pretas e indígenas; e 2 vagas para "outros", respectivamente.

No ano de 2014 a UNIR teve 697 candidatos inscritos para as vagas do primeiro semestre. A Lei $\mathrm{n}^{\mathrm{o}}$ 12.711/2012 previa a aplicação gradativa das reservas de vagas até o percentual de 50\% estipulado pela norma, e a UNIR aplicou no ano de 2014 a reserva de $25 \%$ de vagas para as cotas. Desse modo, o curso de Direito (Porto Velho) que tem uma oferta semestral de 50 vagas, ficou com a divisão de 36 vagas para a ampla concorrência e 14 vagas para as cotas, o dobro de vagas das reservadas para cotas em 2013. Das 14 vagas reservadas para as cotas, no primeiro semestre letivo de 2014, as vagas foram distribuídas em 10 para pessoas autodeclaradas (pardas, pretas e indígenas) e 4 vagas para "outros; do mesmo modo repetiu-se no segundo semestre de 2014.

No ano de 2015 a UNIR teve 1.231 candidatos inscritos para as vagas do primeiro semestre. A Lei de Cotas previa a aplicação gradativa das reservas de vagas para que as IFES pudessem se adequar à normativa. Para o ano de 2015 o percentual previsto era de no mínimo $30 \%$ das vagas. A UNIR, apesar das dificuldades na aplicação da Lei n 12.711/2012, resolveu implementar em 2015 o percentual total mínimo das cotas, 50\%. Com esta medida, o curso de Direito (DCJ) com oferta semestral de 50 vagas, ficou com uma divisão de 25 vagas para a ampla concorrência e 25 vagas para as cotas. Outra mudança nesse ano ocorreu com a disponibilização de vagas para as pessoas com deficiência. Nesta nova modalidade de reserva de vagas foi aplicada de forma que 5\% das vagas da ampla concorrência fossem reservadas às Pessoas com Deficiências (PCDs), no caso do curso de Direito 2 vagas, passando assim a ampla concorrência para 23 vagas e as cotas 27 vagas.

Esses dados confirmam e reiteram a última pesquisa realizada em 2014 e publicada em 2016 pelo FONAPRACE, revelando que a universidade pública caminha na direção de espelhar a composição social atual do Brasil. A universidade pública, em sua maioria, é feminina e cada vez mais popular e negra. O diagnóstico extraído resulta de um processo de democratização do acesso, com programas, tais como o Enem/Sisu e a Lei $n^{\circ}$ 12.711/2012 (Lei de Cotas), que permitiram mais mobilidade territorial e justiça social e étnico-racial (FONAPRACE, 2016, p. 16). 
Verifica-se no lapso temporal de quase 20 anos, de 1996 e 2014, que a composição da sociedade brasileira por cor ou raça também se alterou significativamente. Houve redução da hegemonia de participação da população branca, antes em torno de 55\% e chegando ao final do período a cerca de $45 \%$, e um crescimento significativo da população preta e parda, que saiu de pouco mais de $44 \%$ para pouco mais de $53 \%$. Segundo a pesquisa, é uma mudança significativa para um perfil populacional e que parece estar mais relacionada ao processo de autodeclaração, com a mudança daqueles que se declaravam brancos apenas como um resultado de um racismo latente na sociedade (FONAPRACE, 2016, p. 4).

Esse fator pode ser analisado na tabela 2. Observa-se o quantitativo de vagas disponibilizadas pela Fundação Universidade Federal de Rondônia (UNIR), no curso de Direito, do Campus Porto Velho, destinadas aos cotistas de forma geral, e a quantidade de vagas destinadas aos cotistas negros (pretos e pardos):

TABELA 2: Vagas e quantitativo de cotistas negros: Direito (NUCSA/DCJ ${ }^{5}$ ) Porto Velho

\begin{tabular}{|c|c|c|c|c|}
\hline ANO & $\begin{array}{c}\text { SEMEST } \\
\text { RE }\end{array}$ & $\begin{array}{c}\text { VAGAS } \\
\text { TOTAI } \\
\mathbf{S} \\
\mathbf{5 0}\end{array}$ & $\begin{array}{l}\text { VAGAS } \\
\text { COTAS } \\
\text { GERAL }\end{array}$ & $\begin{array}{c}\text { COTAS } \\
\text { NEGROS } \\
\text { (PRETOS/PAR } \\
\text { DOS) }\end{array}$ \\
\hline \multirow[t]{2}{*}{2013} & $1^{\mathrm{o}}$ & & 7 & $\mathrm{~S} / \mathrm{INF}$ \\
\hline & $2^{o}$ & & 7 & $\mathrm{~S} / \mathrm{INF}$ \\
\hline \multirow[t]{2}{*}{2014} & $1^{\mathrm{o}}$ & & 14 & $\mathrm{~S} / \mathrm{INF}$ \\
\hline & $2^{o}$ & & 14 & $\mathrm{~S} / \mathrm{INF}$ \\
\hline \multirow[t]{2}{*}{2015} & $1^{\mathrm{o}}$ & & 25 & 16 \\
\hline & $2^{o}$ & & 25 & 16 \\
\hline \multirow[t]{2}{*}{2016} & $1^{\mathrm{o}}$ & & 25 & 16 \\
\hline & $2^{o}$ & & 25 & 16 \\
\hline \multirow[t]{2}{*}{2017} & $1^{\mathrm{o}}$ & & 25 & 16 \\
\hline & $2^{o}$ & & 25 & 16 \\
\hline
\end{tabular}

Fonte: Singu e Dirca (Extração 2017-2)

\footnotetext{
${ }^{5}$ NUCSA: Núcleo de Ciências Sociais Aplicadas onde o Departamento de Ciências Jurídicas (DC) e o curso de Direito estão instalados e fazem parte da estrutura organizacional e departamental, localizado no Campus José Ribeiro Filho, Porto Velho-RO. Os demais cursos de Direito da UNIR são oferecidos nos campi de Cacoal e Guajará-Mirim.
} 
Nos processos seletivos de 2013 e 2014, foram implementadas as obrigações estabelecidas na Lei de Cotas. Todavia, em razão do novo procedimento não possuir manuais de padronização por parte do Ministério da Educação (MEC), houve algumas falhas na execução que somente foram corrigidas por recomendação do Ministério Público Federal em Rondônia (MPF-RO). No processo seletivo de 2013 e 2014, todos os cotistas (pretos, pardos, indígenas) concorriam entre si, sem que houvesse qualquer individualização das vagas.

Na publicação do resultado final do processo seletivo de 2013 (UNIR, 2013), não constou o nome dos candidatos aprovados, apenas o Cadastro de Pessoa Física (CPF), número de inscrição no Exame Nacional de Ensino Médico (Enem) e a data de nascimento, sem a identificação dos candidatos aprovados nas cotas que foram disponibilizadas (7 vagas) no curso de Direito para o ingresso nos cursos do primeiro e do segundo semestre. No edital de matrícula do primeiro semestre também não constaram essas informações e acabou por inviabilizar a análise de dados nesse processo seletivo. No edital de matrícula ao ingresso nos cursos do segundo semestre, constou o nome dos candidatos aprovados como cotistas, porém, sem individualização da cota (preto, pardo, indígena).

No processo seletivo de 2014, houve um aumento no número das vagas de cotas, que dobraram de 7 (sete) para 14 (catorze) vagas. O resultado final do processo seletivo foi publicado com o nome dos candidatos, número de inscrição no Enem. Constou os aprovados na condição de cotista. Entretanto, novamente não houve a individualização de acordo com cada tipo de cota (preto, pardo, indígena).

Diante dos conflitos de informações dos processos seletivos de 2013 e 2014 e em razão da Lei de Cotas ainda não ter sido implementada integralmente, optou-se pela análise de dados no curso de Direito em Porto Velho, no período entre 2015 e 2017, referentes ao primeiro e ao segundo semestre, a fim de analisar os percentuais da cota para pretos/pardos, isto é, das 25 (vinte e cinco) vagas para a cota geral, 16 (dezesseis) são para cotistas pretos/pardos.

Com a elaboração da Resolução no 416/Consea/2015, que detalhou cada uma das cotas, em cumprimento à recomendação expedida pelo MPF-RO, facilitaram-se a análise e a publicação dos dados para a sociedade, que passou a entender melhor e a visualizar a quantidade exata de vagas para cada curso na condição das cotas, caso do curso de Direito de Porto Velho. 
QUADRO 1. Perfil cotistas negros: Direito (NUCSA), Porto Velho, 2015.

\begin{tabular}{|c|c|c|c|c|c|c|}
\hline ANO & $\begin{array}{c}\text { SEMESTR } \\
\text { E }\end{array}$ & $\begin{array}{c}\text { COTAS } \\
\text { PRETOS }\end{array}$ & $\begin{array}{c}\text { COTAS } \\
\text { PARDOS }\end{array}$ & $\begin{array}{c}\text { GÊNERO } \\
\text { MAIORIA }\end{array}$ & $\begin{array}{c}\text { FAIXA } \\
\text { ETÁRIA } \\
\text { (MÉDIA) }\end{array}$ & $\begin{array}{c}\text { NATURALIDAD } \\
\text { (MAIORIA) }\end{array}$ \\
\hline \multirow{2}{*}{2015} & $1^{\text {o }}$ & 02 & 14 & $\begin{array}{c}\text { MASCULIN } \\
\text { O } 60 \%\end{array}$ & 25,94 ANOS & PORTO VELHO \\
\cline { 2 - 7 } & $2^{\text {o }}$ & 02 & 14 & $\begin{array}{c}\text { MASCULIN } \\
\text { O } 60 \%\end{array}$ & 33,76 ANOS & $\begin{array}{c}\text { PORTO VELHO } \\
60 \%\end{array}$ \\
\hline
\end{tabular}

Fonte: Eliane Bastos; Singu-UNIR (Extração 2017-2)

Nesta turma do curso de Direito, o ingresso de cotistas no primeiro semestre de 2015 apresentou a maioria dos alunos do gênero masculino: 10 homens e 6 mulheres, com a média de faixa etária em torno de 25 anos. Neste curso, a Escola Estadual de Educação Básica (EEEB) João Bento da Costa, localizada na Zona Sul Urbana de Porto Velho, foi a que mais logrou êxito em inserir 7 (sete) alunos na turma, conferindo que a escola pública de qualidade é crucial ao ingresso no ensino superior público.

A pesquisa conferiu que o ingresso no segundo semestre de 2015 apresentou uma elevada faixa etária para os cotistas negros se comparada aos anos posteriores. Ainda, a maioria dos alunos, de acordo com os dados, é nascida em Porto Velho, porém, aparecem outros com naturalidade em Recife (PE), Ilhéus (BA); e outras localidades do estado de Rondônia: JiParaná, Limoeiro, Pedreiras, Pimenta Bueno. Identificou-se também que esses alunos concluíram o Ensino Médio em escolas públicas não localizadas na capital. Grande parte havia concluído o Ensino Médio há mais de 3 (três) anos.

Na sequência, em 2016, o curso de Direito da UNIR Porto Velho, contou com 17 alunos cotistas matriculados. O número é superior ao previsto, porque houve um cancelamento de matrícula, que é o pedido formal de desistência do curso; normalmente, é feito quando o aluno obteve a aprovação em outro curso de sua preferência ou não mais deseja fazer parte do quadro de alunos da UNIR (o que ocasionou o chamamento de mais um cotista). A escola pública João 
Bento da Costa, novamente, apresentou destaque com a aprovação de 5 alunos.

O semestre letivo de 2015.2 teve 25 vagas para as cotas (50\%), distribuídas em 2 para pessoas autodeclaradas pretas, 14 vagas para autodeclaradas pardas, 1 vaga para indígena e 8 para “demais vagas". Além destas, mais 2 vagas para pessoas com deficiência (5\% ampla concorrência). Destaque para a nota do Enem para ingresso no curso de Direito.

Em 2015.2 com a aplicação de 50\% de reserva de vagas para as cotas, vê-se uma expressiva diferença entre as classificações de ampla concorrência e das cotas, objeto da aplicação das ações afirmativas na UNIR. Sobre as notas do Exame Nacional do Ensino Médio (Enem), temos na tabela 3 as notas dos candidatos:

Tabela 3: Direito Notas (ENEM) 2015.2.

\begin{tabular}{lcc}
\hline & NOTAS AMPLA & NOTAS COTAS \\
\hline Média & 676,8 & 624,7 \\
Mediana & 675,4 & 629,3 \\
Desvio Padrão & 19,5 & 32,6 \\
\hline
\end{tabular}

Fonte: Eliane Bastos. SIGAA/UNIR (2018)

O curso de Direito, da Universidade Federal de Rondônia em geral, teve em 2016 no primeiro semestre, 1.121 candidatos inscritos, sendo 50 vagas oferecidas ao curso de Porto Velho. O ano de 2016 com a aplicação integral dos 50\% das vagas para as cotas, como determina a Lei, ficou com uma divisão no primeiro semestre de 50\% vagas para a ampla concorrência e 50\% das vagas para as cotas. Com um percentual de 5\% de vagas para as pessoas com deficiência, extraído da ampla concorrência o curso de Direito ficou com vagas distribuídas da seguinte forma: 23 vagas para a ampla concorrência e 27 para as cotas (BASTOS, 2018, p. 207); aumento considerável que justifica a implementação da Lei de Cotas, como mecanismo de diminuição da desigualdade social e inclusão do preto/pardo no curso de Direito da UNIR.

A turma de Direito, com ingresso no primeiro semestre de 2017, apresentou a menor faixa etária para os cotistas negros do período de amostra da pesquisa, 20,62 anos, onde o gênero masculino é de 70\%, com apenas cinco mulheres entre as cotistas negras. Ademais, $75 \%$ dos cotistas são oriundos de Porto Velho, e também, 75\% dos cotistas negros da turma concluíram o Ensino Médio em escola pública. Os alunos cotistas que ingressaram no segundo semestre 2017.2 são, em sua maioria, homens, 55\%; com média de idade de 26 anos, a maior parte nascida na cidade de Porto Velho. A implementação dessa política de democratização do 
ensino superior trouxe consigo não somente a possibilidade de entrada na Universidade Federal por parte de uma parcela significativa de alunos socioeconomicamente desprestigiados, como também uma população mais diversificada para o interior dessas instituições. Essa nova configuração compreende, particularmente, o aumento de grupos étnicos minoritários, como negros, pardos e índios, conforme quadro geral da UNIR a partir de 2013:

QUADRO 2: Ingressantes por cotas no ano de 2013

\begin{tabular}{|c|c|c|c|}
\hline \multicolumn{4}{|c|}{ INGRESSANTES POR COTAS NO ANO DE 2013 - TODOS OS CAMPI DA UNIR } \\
\hline \multirow{9}{*}{$\begin{array}{c}\text { TOTAL DE } \\
\text { INGRESSANTES } \\
\text { POR COTAS: } 313\end{array}$} & \multirow{5}{*}{$\begin{array}{l}\text { COM RENDA } \\
\qquad=1,5 \\
\text { SALÁRIOS: } 187\end{array}$} & \multirow[t]{4}{*}{$\begin{array}{c}\text { COM ETNIA } \\
\text { DECLARADA: } 140\end{array}$} & $\begin{array}{l}\text { PARDO: } \\
115\end{array}$ \\
\hline & & & PRETO: \\
\hline & & & 24 \\
\hline & & & $\begin{array}{c}\text { INDÍGENA: } \\
1\end{array}$ \\
\hline & & \multicolumn{2}{|c|}{$\begin{array}{l}\text { SEM ETNIA DECLARADA: } \\
\qquad 47\end{array}$} \\
\hline & \multirow{4}{*}{$\begin{array}{c}\text { COM RENDA } \\
>1,5 \text { SALÁRIOS: } \\
126\end{array}$} & \multirow[t]{3}{*}{$\begin{array}{c}\text { COM ETNIA } \\
\text { DECLARADA: } 89\end{array}$} & $\begin{array}{c}\text { PARDO: } \\
77\end{array}$ \\
\hline & & & $\begin{array}{l}\text { PRETO: } \\
12\end{array}$ \\
\hline & & & $\begin{array}{c}\text { INDÍGENA: } \\
0\end{array}$ \\
\hline & & \multicolumn{2}{|c|}{$\begin{array}{l}\text { SEM ETNIA DECLARADA: } \\
37\end{array}$} \\
\hline
\end{tabular}

Fonte: Dirca (Extração 2018-1)

Com relação a Rondônia, essa tendência intercultural em vigência nas universidades brasileiras, por meio da garantia da presença de uma parcela maior de alunos negros e indígenas, significa a tentativa de superar toda uma trajetória de exclusão de um contingente de pessoas que até há bem pouco tempo não tinha, ou era imensurável, acesso ao ensino superior público e gratuito.

Na UNIR, verifica-se que o número de ingressantes negros nos primeiros anos de aplicação da Lei de Cotas foi de 228 alunos, dos quais a maioria é considerada de baixa renda, ou em situação de vulnerabilidade. Esta ação afirmativa, em conjunto às atividades de ensino, 
pesquisa e extensão, almejam uma trajetória acadêmica de qualidade a esses estudantes, principalmente aos cotistas.

O curso de Direito da Universidade Federal de Rondônia teve em 2018 no primeiro semestre, 927 candidatos inscritos para as 50 vagas do curso. Assim como no ano anterior 2017, também aplicou a reserva de vagas de $50 \%$ para as cotas e manteve os mesmos critérios para o quadro de distribuição e fluxo das vagas distribuídas. Desta forma, o curso de Direito da UNIR em 2018.1, conservou a distribuição em, 25 para a ampla concorrência e 25 vagas para as cotas (ZUIN; BASTOS, 2018). No segundo semestre de 2018.2 repetiu-se a distribuição 25\% para a ampla concorrência e $25 \%$ para as cotas.

De acordo com o IBGE, em pesquisa realizada em 2015, nos últimos anos, mais brasileiros e brasileiras chegaram ao nível superior. Entre 1995 e 2015, a população adulta negra com 12 anos ou mais de estudo passou de 3,3\% para 12\%, aumento de quase quatro vezes, mas, não oculta o fato de a população negra alcançar somente agora ao patamar de 20 anos atrás em comparação com a população branca. O patamar alcançado em 2015 pelos negros era o mesmo que os brancos em 1995. Já a população branca, quando considerado o mesmo tempo de estudo, praticamente dobrou nesses 20 anos, variando de 12,5\% para 25,9\% (IPEA, 2017).

Na UNIR apesar das dificuldades e alguns desafios inerentes à aplicação da Lei de Cotas, conforme mencionado anteriormente, a instituição vem cumprindo sua função no lugar onde se localiza, isto é, no estado de Rondônia, na região Norte, Amazônia Ocidental brasileira, onde de acordo com o Instituto Brasileiro de Geografia e Estatística (IBGE, 2005), a população negra era de 64,2\%; conforme dados do Universo - Indicadores Sociais Municipais, dados sobre a cor ou raça preta/parda, o valor médio do rendimento mensal total nominal (IBGE, 2010, Unidade: B/C ) é de 1,1 salário mínimo.

No último Censo Populacional do IBGE, de 2010, 92,4 milhões de pessoas se declararam de cor branca, o que representava $45,5 \%$ da população. O grupo de pessoas de cor parda representava $45 \%$ do total populacional. Outros $8,6 \%$ se declararam de cor preta (perto de 17,4 milhões de pessoas) e 1,8 milhão de pessoas $(0,9 \%)$ declararam-se de outra cor ou raça (indígenas ou amarelos). Em números atualizados, em 2019, 56,10\% foi o percentual de pessoas que se declaram negras no Brasil, segundo a Pesquisa Nacional por Amostra de Domicílios (Pnad) Contínua do IBGE. Dos 209,2 milhões de habitantes do país, 19,2 milhões se assumem como pretos, enquanto 89,7 milhões se declaram pardos. O Instituto Brasileiro de Geografia e Estatística (IBGE) conceitua os negros como a soma de pretos e pardos, portanto, a maioria da população brasileira é negra. Também, para efeitos de políticas públicas voltadas 
à igualdade racial, são considerados negros (afrodescendentes) os que abrangem pretos e pardos.

Conclui-se que a população negra no Brasil é maioria, mas que não é representada equitativamente nos diversos segmentos sociais, tais como na política e na educação superior, mas que com a implementação da Lei de Cotas, esses números tendem a melhorar e a representar esse universo de cidadãos com dignidade humana e justiça social. $\quad$ Os dados quantitativos são suficientes para ilustrar o alcance da desigualdade enfrentada pela população negra no acesso ao Ensino Superior antes da Lei de Cotas. Nesse aspecto, reside grande parte das reflexões teóricas elaboradas em torno do racismo brasileiro e de suas consequências.

\section{CONCLUSÃO}

As políticas de ações afirmativas aplicadas nas instituições públicas de Ensino Superior, direcionadas ao acesso das populações negras, povos indígenas e estudantes de baixa renda, têm como fundamento a reparação do passado histórico de exclusão dessas populações, os indicadores sociais atuais e a busca por justiça social. Vivendo, em sua maioria, nas periferias das cidades, sem acesso à moradia, saúde ou educação, a população negra passou por muitos anos de segregação e impedimento ao ingresso no Ensino Superior. Dados apontam que nos dias atuais essa população (os negros) têm os piores indicadores sociais, como renda, escolaridade, acesso a bens e serviços, e sofrem com os maiores índices de violência e morte.

Nesse contexto, vale destacar que a Lei $n^{\circ}$ 12.711/2012 - a Lei de Cotas - é resultado das lutas e reivindicações dos movimentos negros à criação e implementação de políticas públicas que compensassem e redistribuíssem de forma igualitária e justa as riquezas produzidas no território brasileiro, inclusive o conhecimento socialmente produzido, configurado no direito à educação; direito que demorou a ser expresso nas constituições brasileiras como apresentado nesse estudo, no histórico constitucional, vindo a tornar realidade na Constituição da República Federativa do Brasil, em 1988, art. 205.

Apesar da Carta Magna de 1988 conferir que a educação é direito de todos, e em seu preâmbulo definir o Brasil como um Estado democrático, destinado a "assegurar o exercício dos direitos sociais e individuais, a liberdade, a segurança, o bem-estar, o desenvolvimento, a igualdade e a justiça como valores supremos de uma sociedade fraterna, pluralista e sem 
preconceitos", a população negra ainda não conseguia o devido acesso às escolas e à universidade pública, na mesma proporção que os brancos.

$\mathrm{Na}$ tentativa de amenizar os problemas decorrentes do ingresso de negros nas instituições públicas de Ensino Superior, a implementação na Universidade Federal de Rondônia das cotas e da reserva de vagas no processo seletivo discente resultou em uma política com e para a justiça social. No que tange ao objetivo específico, acerca de detectar o perfil dos alunos cotistas matriculados no curso de Direito do campus de Porto Velho, constatamos que os estudantes de escolas públicas passaram a ter um percentual maior com as cotas de $50 \%$. No ano de 2017, com a aplicação legal de 50\% de reservas de vagas, verificou-se que o curso passou a ter mais pessoas autodeclaradas pretas/pardas. $\mathrm{O}$ aumento do número de vagas à população preta/parda, conforme pode ser observado pela distribuição das cotas desde 2013 a 2018.1, contribuiu para a inclusão e a justiça social dessa população no curso de Direito; curso, já conhecido há tempos, que servia mais à classe média, alta e aos brancos.

Embora, a Universidade Federal de Rondônia (UNIR) não possui, até o momento, a unidade organizacional ou setor em sua estrutura, responsável pelo acompanhamento e/ou avaliação da ação afirmativa da Lei de Cotas voltadas ao ingresso da população negra, indígena, pessoas com deficiência, estudantes oriundos de escolas públicas em situação de vulnerabilidade social, os dados apresentados neste estudo dão indicativos da sua positividade, porque a implementação dessa política de democratização do ensino superior trouxe consigo não somente a possibilidade de entrada na Universidade Federal de Rondônia, de uma parcela significativa de alunos socioeconomicamente desprestigiados, mas também uma população mais diversificada para o interior da instituição. Essa nova configuração compreende, particularmente, o aumento de grupos étnicos minoritários como negros/pardos conforme os números apresentados a partir de 2013 a 2018.1, no curso de Direito. Assim, a diversidade agora é proporcionada por meio das cotas, logo, o curso de Direito passou a se compor, a partir do ano de 2017 , de $55 \%$ de pardos, $30 \%$ de brancos, $8 \%$ de pretos, $6 \%$ de indígenas e $1 \%$ de amarelos. Os resultados dos dados do curso de Direito são inegáveis no quesito transformação do perfil "cor/raça/etnia" dos alunos ingressantes.

\section{REFERENCIAS}

BASTOS, Eliane. Aplicação da Lei de Cotas nos cursos de Direito e Medicina da Universidade Federal de Rondônia Campus Porto Velho: política de ação afirmativa por 
justiça social com equidade. 2018. 337f. Dissertação (Mestrado Acadêmico em Educação). Fundação Universidade Federal de Rondônia, Porto Velho, RO, 2018.

BRANDÃO, Carlos da Fonseca. As Cotas na Universidade Pública Brasileira: Será esse o caminho? Campinas: Autores Associados, 2005.

BRASIL. Lei 1831 de 7 de novembro de 1831. Legislação Informatizada - Lei de 7 de Novembro De 1831 - Publicação Original. Disponível em:

https://www2.camara.leg.br/legin/fed/lei_sn/1824-1899/lei-37659-7-novembro-1831-564776publicacaooriginal-88704-pl.html. Acesso em: 13 maio 2020.

BRASIL. Lei $\mathbf{n}^{\mathbf{0}} 3.353$ de 13 de maio de 1888. Disponível em: http://www.planalto.gov.br/ccivil_03/leis/lim/LIM3353.htm. Acesso em: 13 maio 2020.

BRASIL. Constituição da República dos Estados Unidos do Brasil de 1891. Rio de Janeiro, 1891. Disponível em: <http://www.planalto.gov.br/ccivil_03/Constituicao/Constituicao91.htm>. Acesso em: 31 out. 2018.

Constituição da República dos Estados Unidos do Brasil de 1934. Rio de Janeiro, 1934. Disponível em:

<http://www.planalto.gov.br/ccivil_03/Constituicao/Constituicao34.htm>. Acesso em: 31 out. 2018.

Constituição da República dos Estados Unidos do Brasil de 1937. Rio de Janeiro, 1937. Disponível em: <http://www.planalto.gov.br/ccivil_03/Constituicao/Constituicao37.htm>. Acesso em: 31 out. 2018.

. Constituição da República dos Estados Unidos do Brasil de 1946. Rio de Janeiro, 1946. Disponível em:

<http://www.planalto.gov.br/ccivil_03/Constituicao/Constituicao46.htm>. Acesso em: 31 out. 2018.

Constituição da República Federativa do Brasil de 1967. Brasília, 1967.

Disponível em: <http://www.planalto.gov.br/ccivil_03/Constituicao/Constituicao67.htm>. Acesso em: 31 out. 2018.

. Constituição da República Federativa do Brasil de 1988. Brasília, 1988.

Disponível em: <http://www.planalto.gov.br/ccivil_03/constituicao/constituicao.htm>. Acesso em: 25 mai. 2018.

Lei $\mathbf{n}^{\circ} 12.711$ de 29 de agosto de 2012. Cotas Presidência da República - Casa Civil - Subchefia para Assuntos Jurídicos.. Disponível em: <http://www.planalto.gov.br/ccivil_03/_ato2011-2014/2012/lei/112711.htm>. Acesso em: jul. 2018.

CURY, Carlos Roberto Jamil. Educação e Direito à Educação: Um histórico pelas constituições. Belo Horizonte, Mazza Edições, 2014.

FANON, Frantz. Pele negra, máscaras brancas. Tradução de Renato da Silveira. Salvador: EDUFBA, 2008.

FONAPRACE. Fórum Nacional de Pró-Reitores de Assuntos Comunitários e Estudantis. Disponível em: IV Pesquisa do perfil socioeconômico e cultural dos estudantes de graduação das instituições federais de ensino superior brasileiras - 2014. Andifes. Minas Gerais, Uberlândia, 2016. 
FONAPRACE. Fórum Nacional de Pró-Reitores de Assuntos Comunitários e Estudantis. V Pesquisa Nacional de Perfil Socioeconômico e Cultural dos (as) Graduandos (as) das IFES - 2018. Andifes. Minas Gerais, Uberlândia, 2018.

FREIRE, Paulo. Pedagogia do Oprimido. Rio de Janeiro: Paz e Terra, 1988.

GUIMARÃES-IOSIF, Ranilce. Educação, pobreza e desigualdade no Brasil. Brasília: Líber Livro, 2009.

GHIRALDELLI JUNIOR, Paulo. História da Educação Brasileira. 4. ed. São Paulo, Cortez, 2009.

IBGE. Pesquisa Nacional por Amostra de Domicílios. PNAD 2005. População, por Raça/Cor Unidades da 2005.20 Disponível em: http://produtos.seade.gov.br/produtos/idr/download/populacao.pdf. Acesso em: 12 abr. 2019.

IBGE. Universo - Indicadores sociais municipais / Razão / Cor ou raça / Preta/Parda / Valor médio do rendimento mensal total nominal. Unidade: B/C. Disponível em: https://cidades.ibge.gov.br/brasil/ro/portovelho/pesquisa/23/25124?tipo $=$ ranking\&indicador $=29535 \&$ localidade $2=0$. Acesso em: 15 fev. 2019.

IPEA. Instituto de Pesquisa Econômica Aplicada. Estudo mostra desigualdades de gênero e raça em 20 anos. Disponível em:

http://www.ipea.gov.br/portal/index.php?option=com_content\&view=article $\&$ id $=29526$

Acesso em: 28 out. 2018.

OLIVEIRA, Graziela de. O negro na História da Educação Superior no Brasil. Universidade e Sociedade, v. 34, ano XIV, outubro de 2004.

SANTOS, Dyane Brito Reis. Para além das cotas: a permanência de estudantes negros no ensino superior como política de ação afirmativa. Salvador: UFBA, 2009. Tese de Doutorado. 311 f. Doutorado em Educação, Universidade Federal da Bahia, 2009.

SANTOS, João Paulo de Faria. Ações afirmativas e igualdade racial: a contribuição do direito na construção de um Brasil diverso. São Paulo. Edições Loyola, 2005.

SAVIANI, Demeval et al. O legado educacional do século XIX. 2. ed. rev. e ampl. Campinas: Autores Associados, 2004.

SILVA, José Afonso da Silva. Poder Constituinte e Poder Popular (estudos sobre a Constituição). São Paulo: Malheiros, 2007.

SILVA, Geraldo da, ARAÚJO, Márcia. Da Interdição Escolar às Ações Educacionais de Sucesso: Escolas dos movimentos negros e escolas profissionais, técnicas e tecnológicas. In:

ROMÃO, Jeruse (org.). História da Educação do Negro e Outras Histórias. Brasília: Ministério da Educação, Secretaria de Educação Continuada, Alfabetização e Diversidade, 2005. pp. 65-78.

TEIXEIRA, Anísio S. Educação e o mundo moderno. São Paulo: Nacional, 1969.

UNIR. Diretoria de Registro e Controle Acadêmico. Disponível em: 
http://www.dirca.unir.br/. Acesso em: 09 jun. 2018.

UNIR. Processo Seletivo. Disponível em: http://www.processoseletivo.unir.br. Acesso em: 23 maio 2018.

UNIR. Vestibular. Disponível em: http://www.vestibular.unir.br/. Acesso em: 15 jul. 2018.

ZUIN, A. L.; BASTOS, E. A justiça social por meio das cotas na Universidade Federal de Rondônia. Educação \& Formação, v. 4, n. 12set/dez, p. 104-123, 18 jun. 2019.

Trabalho recebido em 15 de maio de 2020 Aceito em 14 de maio de 2021 